\title{
Kurumsal Bilginin Stratejik Planlama Sürecinde Kullanılması: Bir İlçe Belediyesi Örneği
}

The Use of Organizational Knowledge in the Process of Strategic Planning: An Example of a City Municipality

\section{Berat Bir BAYRAKTAR $^{*}$ ve Asiye Kakırman YILDIZ}

\begin{abstract}
Öz
Bu çalışmanın amacı, kurumsal bilgi ve stratejik planlama kavramlarının kurumlar için olan önemini ortaya koymak ve bu iki kavram arasındaki ilişkiyi tespit edebilmektir. Bu nedenle, İstanbul Büyükşehir Belediyesi'ne bağll, bir ilçe belediyesinde bir alan çalışması yapılmış ve ilgili belediyenin stratejik planını hazırlarken kurumsal bilgiden ne derece istifade ettiği incelenmiştir.
\end{abstract}

Anahtar sözcükler: Stratejik planlama, Kurumsal bilgi.

\begin{abstract}
The purpose of this study is to underline the importance of the concepts of organizational knowledge and strategic planning for organizations and to define the relationship between these concepts. A case study was carried out in an Istanbul municipality to demonstrate how the municipality administration made use of the organizational knowledge in strategic planning.
\end{abstract}

Keywords: Strategic planning, Organizational knowledge.

`Yrd. Doç. Dr.; Marmara Üniversitesi, Fen Edebiyat Fakültesi, Bilgi ve Belge Yönetimi Bölümü (beratbirfin@superonline.com)

"Arş. Gör.; Marmara Üniversitesi, Fen Edebiyat Fakültesi, Bilgi ve Belge Yönetimi Bölümü (akakirman@marmara.edu.tr) 


\section{Giriş}

21.yüzyılda kurumlar, küreselleşme, hızlı teknolojik gelişim, yeni oluşan pazarlar, insanların ihtiyaçlarının ve beklentilerinin değişmesi sonucunda ortaya çıkan değişim ve devamlı olarak artan rekabet ortamı karşısında, eskisinden daha stratejik düşünmekte ve stratejik planlama yapma, stratejik kararlar alma faaliyetlerine daha fazla önem vermek zorunda kalmaktadırlar (Aktan, 2003).

Küresel rekabet ve değişim, iş dünyasının şeklini değiştirmiş, bütün kuruluşların üzerinde önemli bir baskı oluşturmuştur. Bu baskı neticesinde kurumlar, bilgi yönetiminden elde edilebilecek uzun vadeli rekabet avantajını sağlamak için, iç ve dış bilgi kaynaklarına etkili bir biçimde erişilmesinin ve bu bilgi kaynaklarının kullanılmasının kaçınılmaz olduğunu kabul etmişlerdir (Odabaş, 2003, s.366).

Hızlı değişim, geçmiş deneyimlerden elde edilen sonuçlara göre, geleceği büyük oranda tahmin edebilme rahatlığını da ortadan kaldırmış bulunmaktadır. Ortamın bu derece belirsizleşmesi, kurumların yeni stratejiler geliştirmesini, gelecekteki eğilimleri ve çevre şartlarındaki değişimleri de hesaplayarak stratejik planlar yapmalarını gerekli hale getirmiştir. Bir başka deyişle, gelecekçi (futuristik) yönetim anlayışlarını benimsemeye yönelik eğilimler geliştirmişlerdir.

Stratejik planlama konusunda genellikle kâr amaçlı kurumlar ele alındığı ve genellikle kamu kurumlarının yönetim literatüründeki uygulamalara karşı kapalı bir tutum sergilediği için, örnek olarak, İstanbul Büyükşehir Belediyesine bağlı bir kamu kuruluşu olan bir ilçe Belediyesi alınmıştır.

Belediyeler, toplumsal sorumluluk gereği, toplumsal dinamizme ayak uydurmak zorunda olan kurumlardır. Bir özel sektör mantığıyla hareket etmek durumunda olan belediyeler, gelişen ve değişen intiyaçlara bağlı olarak, insanların taleplerine cevap verebilmesi için gelişim ve değişim içinde olmak zorundadır. Vatandaş, bir belediye için müşteridir ve müşteri odaklılık anlayışı içinde, vatandaşın taleplerini, beklentilerini ve intiyaçlarını, 
maksimum ölçüde karşılamak ve onları memnun etmek zorunluluğu vardır.

Bu anlayıştan yola çıkarak, 2004 yılında stratejik planlamasını hazırlamış olan söz konusu belediyede, stratejik plan hazırlanırken kurumsal bilginin ne anlam ifade ettiği, ne derece referans alındığı, stratejik planlama sürecine ne ölçüde yansıtıldığı ve stratejik planlama süreci için kurumun arşivinden istifade edilip edilmediği incelenmeye çalışılmıştır.

Değişen ve sürekli gelişen ortam koşulları karşısında kurumlar, rekabet ortamının hangi fırsatları ya da tehditleri getireceğini bilememektedir. Böylesine belirsiz bir ortamda rekabet gücünü korumak isteyen kurumların, esnek ve hızlı stratejiler geliştirmesi, diğer bir deyişle değişimi yönetmesi gerekmektedir (Yazıcı, 2001, s.103). Çünkü teknolojinin gelişme hızının artması hem yenilikleri hızlandırmakta, hem de hızlanan yeniliklerin insanlara daha hızlı ulaşmasını sağlamaktadır.

Strateji, müşterilerin henüz düşünmedikleri yeni yararları onlar adına düşünmeyi gerektirir. Dolayısıyla strateji, bir şeyi daha iyi yapmakla ilgili değil, daha farklı yapmakla ilgilidir (Kırım, 1998, ss.25-26). Buna bağlı olarak kurumların rakipleri karşısında başarı elde edebilmelerinin temel şartı kurumsal stratejilerini oluşturmaktır. Zira genellikle ayakta durabilen kurumlar kısa dönemli acil sorunlarla uğraşan değil, geleceğe dönük stratejik düşünen ve hazırlıklarını buna göre yapan kurumlardır. Diğer bir deyişle başarılı kurumlar, değişken piyasa koşullarında oradan oraya sürüklenen değil, kendi elleriyle kendi geleceklerini şekillendiren, sağlam organizasyon yapıları kuran, yönetim anlayışlarıyla farklılık yaratabilen kurumlardır (Argüden, 2004, s.71).

$\mathrm{Bu}$ çalışmanın amacı, "bilgi çağı" olarak da adlandırılan 21.yüzyılın intiyaçlarına bağlı olarak, hem rakipleri karşısında yaşama stratejileri belirleyebilmek, hem de gelecek odaklı ilerleme stratejileri hazırlayabilmek için e-dönüşüm, e-öğrenme, toplam kalite yönetimi (TKY), ISO ve stratejik planlama gibi çalışmalar yapan bir belediyede gerçekleştirilmiş olan stratejik planlama sürecini incelemek ve çalışma sonucu elde edilen bu belediyeye 
ait stratejik planın içeriklerini bulgu ve sonuçlarıyla ortaya koymaktır.

Öncelikle stratejik planlama süreci, planlama öncesi, planlama süreci ve sonrası olarak üç kısımda değerlendirilmeye çalışılmıştır. Buna göre, bilimsel olarak kabul edilen stratejik plan örneğine uygun biçimde, belediyenin tüm birimlerinin başkan ve yardımcılarıyla görüşülerek, hem belediyenin tarihçesi ve kurumsal yapısıyla ilgili hem de, stratejik planlama sürecine yönelik olarak neler yaptıklarına dair, ayrıntılı bilgi ve belgeler toplanmıştır. Bu bilgi ve belgeler arasında birimlerin iş ve görev tanımları, çalışma yönetmelikleri, yıllık faaliyet raporları ve stratejik planlama toplantı tutanakları sayılabilir. Yaklaşık altı ay alan bu süreçten sonra, elde edilen veri ve bilgiler doğrultusunda, ilgili belediyenin kurumsal bilgi kaynakları ortaya konulmuştur. Burada da, daha önce bu makalede de sözü edilmiş olan bir kurumun genelde var olan bilgi kaynakları baz alınmış ve buna göre bir sonuç çıkarılmıştır.

Son olarak, söz konusu belediyenin stratejik planının son ve mevcut durumuna yönelik tüm belgelere ulaşılarak, gerekli analizler yapılmış ve ortaya çıkan tablo, bu çalışmanın içeriğini oluşturacak şekilde raporlanmıştır.

\section{Araştırmanın Metodu}

Çalışma için öncelikle bir stratejik planlama sürecinin hangi aşamalardan oluştuğuna ilişkin literatür incelenmiştir. Edinilen bilgiler çerçevesinde, stratejik planlama sürecinde yer alan belediyenin tüm birimlerinin, başkan ve başkan yardımcılarıyla yüz yüze görüşmelerde yöneltilecek sorular hazırlanmıştır. Görüşmeler sırasında yöneticilerden alınan bilgiler, konu ile ilgili toplanan belgeler incelenmiştir.

\section{Kurumsal Bilgi Kavramı ve Kurumsal Bilginin Unsurları}

Kurumların, rakiplerinden daha farklı olmasını, aynı işi rakiplerine göre daha farklı yapmasını ve tüm kurumların aynı yöntemleri uyguladığı bir ortamda rekabet güçlerinin artmasını sağlayacak tek bir güç vardır: "Kurumsal bilgi".

Teknolojiler, teknikler ve insanlar arasındaki karşılıklı etkileşim sonucunda oluşan kurumsal bilgi kavramının içine müşteriler, 
ürünler, süreçler, hatalar ve başarılar hakkındaki her tür bilgi girer. Kurumsal bilgi belli bir zaman süreci içinde oluşur ve kurumun değişimle mücadele etmesine ve rekabet avantajı sağlamasına olanak verir.

Her gün yeniden şekillenen ve kurumların yapısında da değişikliğe neden olan rekabet ortamında, kurumların beklenmedik durumlar karşısında tepki gösterebilmesi, rekabet gücünün en önemli göstergelerindendir. Kurumların bu gücü ellerinde bulundurmaları ise, kurumsal bilginin doğru kullanılmasıyla ilgilidir.

Kurumsal bilgi, kurum için sürdürülebilir rekabet avantajı sağlayan bir kaynaktır. Kurumun rekabet avantajı elde etmesi ve sürdürebilmesi, o kurumun rakiplerinin uygulayamayacağı ya da taklit edemeyeceği, kendine özgü bir strateji geliştirebilmiş olmasına bağlıdır (Barca, 2002, s.65). Kurumun kendine özgü bir strateji geliştirebilmesi ise, gerekli bilgi ve kaynak birikimi ile mümkündür.

Geleneksel anlamda uluslararası kurumlar, standart iş yapma yöntemlerini dünyanın her köşesinde uygulamaya çalışırlar. Yeni yönetim anlayışını benimseyerek kendilerine adapte eden ve böylece dünyadaki etkinlik alanlarını genişleten kurumlar ise bilgi birikimlerini kullanarak hem farklı pazarlara farklı çözümler sunar, hem de bu başarılarıyla fark yaratırlar (Argüden, 2004, s.73). Dolayısıyla yeni yönetim anlayışı kurumların tek merkezden değil, çok merkezden yönetilmesini telkin eder. İletişim ve uygulama hızının başarı için en önemli faktör oluşu, kurumları tek merkezden çok merkeze doğru yönelmesini gerektirir. Buna bağlı olarak kurumların başarılı olmasındaki belirleyici etken, kurumun organizasyon şeması ya da yönetim yapısı değil, yönetim anlayışıdır. Çünkü, hem kurumsal bilginin gelişmesi için gereken ortam, hem bilginin etkili ve etkin yönetilmesi, hem de çalışanların davranışları, yönetim anlayışına bağlı olarak şekillenmektedir.

Yukarıda bahsedildiği üzere, kurumun faaliyetleri sırasında üretilen kurumsal belgeler, kurumsal bilginin temel taşıyıcısıdır ve kurumun, kurum çalışanlarının, ortaklarının, müşterilerinin ve halkın hak ve yetkilerini güvence altına alması bakımından son derece önemlidir. Kurumsal bilginin unsurları aşağıda tanımlanmıştır: 


\section{Kurumsal Belge Unsuru}

Kurumlarda en sık rastlanan belgeler genel olarak talimatlar, formlar, raporlar ve yazışmalardan oluşmaktadır.

\section{Talimatlar}

Genel olarak talimatlar, bir kurumda çalışan personelin neyi, ne zaman, nasıl yapacağı ve işlemlerin nasıl uygulanacağı ile ilgilidir. Kurumsal açıdan, talimatların oluşturulmasının amacı standardizasyon olarak düşünülebilir. Çünkü talimatlardan edinilen bilgi sayesinde kurumda, farklı zamanlarda aynı işler, aynı işlemlerle yapılacağından, belli bir standart elde edilecek, bu da kurumun faaliyetlerinin etkin ve verimli bir biçimde devam etmesine olanak sağlayacaktır. Aksi takdirde yapılan işlerde tekrarlamalar, farklılıklar ve karar vermede güçlükler baş gösterecektir.

\section{Formlar}

Kurumsal bilgi kaynaklarından biri olan formlar, bilgiyi toplamak, düzenlemek ve nakletmek için kullanılan araçlardır. Kurum intiyaçlarına ve istenen bilgiyi elde etmeye yönelik olarak tasarlanmış olan formlardan elde edilen net bilgiler neticesinde, kurumdaki iş akışı hızlanır ve verimlilik artar.

\section{Raporlar}

Her kurum ve yönetim için vazgeçilmez temel bir araç ve yönetimde önemli kararlar almada gerekli bir bilgi kaynağı olan raporlar, genellikle kurumların aylık veya yıllık toplantıları sonucunda ve kurum içinde ya da kurum dışında ortaya çıkan intiyaçlara göre hazırlanırlar. Bu nedenle, içerdikleri bilgi, süratli ve doğru karar vermek durumunda olan yöneticiler için son derece önemlidir.

\section{Yazışmalar}

Belge denilince akla ilk gelen belge türlerinden biri de yazışmalardır. Yazışmalar iki yönlü olduğu için hem kurumsal yani iç bilgiyi, hem de kurum dışı yani dış bilgiyi intiva ederler. Son yıllarda bilgisayar teknolojisinin kurum ve kuruluşlarda yoğun olarak kullanılmasıyla birlikte belge üretiminde ve kayıtlı belge sayısında büyük artışlar olmuştur. Belge üretim miktarını artması 
neticesinde hem verilen hizmetin maliyeti artmakta, hem de belge erişimine yönelik işlemlerde karışıklıklara neden olmaktadır. (Odabaş ve Rukancı, 2004, s.386). Dolayısıyla yazışmaların tanımlanması, düzenlenmesi, saklanması ve korunmasına, kurumun faaliyetlerinin sağlıklı bir biçimde yürüyebilmesi için büyük önem göstermek gerekmektedir. Zira, karşı taraftan istenen bir cevabın bilgi eksikliğinden dolayı zamanında verilememesi, ya da karşı tarafa gönderilen bir yazıda belirtilen hususların yanlış ya da eksik olması, kurumun faaliyetlerini sekteye uğratarak itibarını zedeleyecektir.

\section{Entellektüel Sermaye Unsuru}

Entellektüel sermaye, kurumun maddi olmayan varlıkları olarak tanımlanmaktadır. Kurumun gelecekteki başarısı, bugün sahip olduğu entellektüel sermayenin nasıl yönetildiğine bağlıdır (Büyüközkan, 2003).

Entellektüel sermaye konusunda genel olarak kabul edilen görüş, entellektüel sermayenin "bir kurumun sahip olduğu ve muhafaza altına aldığı bilgi" olduğu yönündedir. Kurumun entellektüel sermayesi insan, kurum ve müşteri sermayesinin toplamından oluşur.

Entellektüel sermayenin temelini oluşturan çalışanlara ait entellektüel sermaye, kurum çalışanlarının sahip olduğu özel ve farklı bilgilerden oluşur. Kurum çalışanlarının sahip olduğu özel ve farklı bilgiler ise müşteriler, ürünler, süreçler, hatalar ve başarılar hakkındaki her şeyden oluşmaktadır. Bu bilgi, kuruma rekabet avantajı sağlayan iş bilgisi birikimi (know-how) veya çalışanların bilgi birikimlerinin sonucudur.

Entellektüel sermayenin kurum tarafından oluşturulan ve kuruma ait olan unsuru, Kuruma ait entellektüel sermayedir. Bunlar, kurumun doğal faaliyetleri ve yasal yükümlülükleri sonucunda üretilen ve kullanılan belgeler ve çeşitli yayınlardan oluşan entellektüel kaynaklardır (Özdemirci ve Aydın, 2007, s.175). Kurum sermayesi, bilginin kurumsal faaliyetlerde kullanılmasını teşvik eden kurumsal niteliklerin toplamıdır. Ayrıca, insan sermayesi ile müşteri sermayesi arasındaki bilgi akışını sağlayan kanaldır. 
Entellektüel varlıklar içinde en zor ulaşılan müşterilere ait entellektüel sermayedir. Çünkü bilginin kurum dışı kaynaklardan kurumun içine akışı sağlanmak zorundadır. Müşteri sermayesi, kurum için katma değer yaratabilecek kurum dışı tüm taraflarıyla ilgilidir. Keza müşteri sermayesinin başlıca unsuru bilgidir (Arıkboğa, 2003, s.102).

Peter Drucker'a (1994, s.132), göre, kurumların birbirinden farklı ekonomik değerlere sahip olması, aslında birbirlerinden farklı olmalarının sonucudur. Bu farklılığın kaynaklarından biri de kurum çalışanlarıdır. Drucker'a göre bu kaynağın kurum için rekabet avantajı yaratması, kurumun varlığını sürdürmesi ve büyümesi, kurumda çalışan bir grup insanın elinde tuttuğu özel ve farklı bilgide gizlidir.

\section{Stratejik Planlama Süreci}

Stratejik planlama, bugünden geleceği elde etmek isteyen kurumların amaçlarını, hedeflerini ve bunlara ulaşmayı mümkün kılacak yöntemlerin belirlenmesini sağlamaktadır. Bunun yanı sıra, kurum bütçesinin, stratejik planda ortaya konulan amaçlara paralel olarak hazırlanmasına ve kaynakların doğru tahsis edilmesine rehberlik etmektedir.

Stratejik planlamada önemli olan gelecek kavramı olmakla birlikte, stratejik planlamanın amacı geleceğin şekillendirilmesi için, yarın ne yapılması gerektiğini belirlemek değil, aksine, yarına sahip olabilmek için, bugün ne yapılması gerektiğine karar vermektir (Elma ve Demir, 2003, s.300).

\section{Strateji}

Strateji kelime anlamı itibariyle Latince yol, çizgi kavramlarından ve yönetimin başı anlamına gelen "strategos" kelimesinden türemiştir. İlk olarak askeri alanda kullanılmış olan strateji kelimesi bu alanda, sonuç alıcı harekatların planlanması ve yönetimi olarak tanımlanmıştır. Bir kurum açısından ise strateji, kimin, hangi intiyacının, nasıl karşılanacağı konusunda mantıklı ve tutarlı tercihlerde bulunarak (Argüden, 2004, s.90) kurumun performansını artırmayı amaçlayan rehber olarak tanımlanabilir. 
Değişen ve sürekli gelişen ortam koşulları karşısında kurumlar, rekabet ortamının hangi fırsatları ya da tehditleri getireceğini bilememektedir. Böylesine belirsiz bir ortamda rekabet gücünü korumak isteyen kurumların, esnek ve hızlı stratejiler geliştirmesi, diğer bir deyişle değişimi yönetmesi gerekmektedir (Yazıcı, 2001, s.103). Çünkü teknolojinin gelişme hızının artması, hem yenilikleri hızlandırmakta, hem de hızlanan yeniliklerin insanlara daha hızlı ulaşmasını sağlamaktadır.

\section{Planlama}

Strateji uzun süreli amaçlar ve seçimlerle ilgiliyken, planlama amaçlara ulaşmak için kullanılacak araçların ve yolların belirlenmesi ve neyin nasıl yapılacağının tespit edilmesiyle ilgilidir. Dolayısıyla planlama, strateji, politika, yöntem ve program kavramlarının bütününü kapsayan bir süreçtir (Eren, 1990, s.14).

\section{Planlama Süreci}

Yönetimin temel fonksiyonlarından birincisi olan planlama süreci, kurumun diğer fonksiyonlarının yerine getirilmesine zemin teşkil eder. Kurumun amaçlarıyla doğru orantılı yapılan planlama, kurumsal kaynakların doğru yerlere, doğru şekilde aktarımını sağlayan bir fonksiyondur. Illeriye dönük bir faaliyet olarak planlama, şu sorulara cevap bulma işlevini görür ve bu sorular şu faydaları sağlar (Dalay, 2001, s.293):

> Ne yapılacak? Yapılacak işin niteliğinin belirlenmesine ve amaçların tekrar gözden geçirilmesine yardımcı olur.

$>\quad$ Ne zaman yapılacak? Planlama sürecinin başlama ve bitiş tarihlerinin belli olmasını sağlar.

$>$ Nasıl yapılacak? Gerçekleştirilecek olan amaca nasıl ulaşılacağı, hangi yolun izlenmesi gerektiği, hangi metodun uygulanması gerektiği konusunda yardımcı olur.

$>$ Nerede yapılacak? Çalışmanın yerinin ve alanının belirlenmesine ve nerede başlayıp nerede biteceğinin bilinmesine olanak sağlar.

> Niçin yapılacak? Bu soru planlama sürecinin kontrol edilmesine imkân tanır. Yukarıda açıklanan ne, ne zaman, nasıl ve nerede 
sorularına niçin sorusu yöneltildiği zaman, planlamanın başarıyla gerçekleşip gerçekleşmeyeceği belli olur.

> Kim yapacak? Planlama sürecinin liderinin, yetkin özelliklere sahip olup olmadığını inceleyen bir sorudur. Planlamayı niçin o kişinin yaptığı, başka kimin yapabileceği ve kimin yapmasının en uygun olacağı ile ilgili bilgiler elde edilmesini sağlar.

\section{Stratejik Planlama}

Stratejik planlama ile ilgili olarak pek çok tanım yapılmış olmakla birlikte genel olarak kabul edilen, stratejik planlamanın kurumun bulunduğu noktadan amaçladığı noktaya varmasını sağlayan işlemlerin toplamı olduğudur.

\section{Araştırmadan Elde Edilen Bulgular}

\section{Belediyenin Stratejik Planlama Sürecinin Tarihsel Gelişimine Ait Bilgiler}

5018 sayılı Kanun, yanısıra 5393 sayılı Belediye ve 5216 sayılı Büyükşehir Belediyesi Kanunlarına göre, nüfusu 50 binin üzerindeki belediyeler stratejik plan hazırlamakla yükümlüdürler (Kamuda Stratejik Yönetim, 2003). Buna göre; belediyelerde stratejik planlamayla, politika belirleme ve maliyetlendirme, kapasitesinin güçlendirilmesi, amaç ve hedeflere dayalı yönetim anlayışı, bütçelemenin geliştirilmesi, kamu hizmetlerinin arzında yararlanıcı taleplerine duyarlılığın artırılması ve hesap verme sorumluluğunun tesis edilmesi amaçlanmaktadır.

Araştırmamıza konu olan Belediye, 1992 yılında kurulmuş olup, 1 başkan ve 2 başkan yardımcısına bağlı 22 müdürlükle faaliyet göstermektedir. Belediye kapsamında, e-devlet, ISO 9000, ISO 9001, TKY ve stratejik planlama çalışmaları yapılmıştır. Stratejik planlama çalışması 2003 yılında tamamlanmış olup diğer çalışmalar devam etmektedir.

Belediye stratejik planlama çalışmalarına 17 Şubat 2003 tarihinde başlanmış, 4 Nisan 2003 tarihinde tamamlanmıştır. Yaklaşık olarak iki ay süren çalışmaya, 10 kişiden oluşan planlama komitesinin yanı sıra, belediyenin tüm birimlerini ve her kademe çalışanını temsil edecek olan 5 ayrı çalışma grubundan bireyler katılmıştır. Bu çalışma grupları şunlardır: 
1. Stratejik planlama grubu

2. Eğitim grubu

3. Öneri/Şikayet grubu

4. Toplantı grubu

5. Öz değerlendirme grubu

Belediyenin stratejik planı hazırlanırken, ilk etapta tüm birimlerden kendilerine ait misyon, vizyon ve hedefler bildirimi istenmiş ve bunlara göre kurumsal bir misyon, vizyon ve hedefler bildirimi oluşturulmuştur. Ardından SWOT (Güçlü yönler, Zayıf yönler, Fırsatlar, Tehditler) analizi yapılarak kurumun güçlü ve zayıf olduğu yönler ile fırsat ve tehdit unsurları belirlenerek stratejik plan amaçlara bağı olarak değerlendirilmiş ve aksak yönler düzeltilerek uygulamaya devam edilmiştir.

\section{IIIgili Belediyenin Stratejileri}

Stratejik planlama sürecinde elde edilen bilgilere dayanılarak ilgili belediyenin kurumsal stratejileri oluşturulmuş ve belirlenen stratejiler aşağıda listelenmiştir.

\begin{tabular}{|r|l|}
\hline No & \multicolumn{1}{|c|}{ STRATEJi } \\
\hline 1 & $\begin{array}{l}\text { Ekip ruhunu canlandıracak eğitimlerin yapılması ve takım } \\
\text { çalışmalarının önemini her düzeyde vurgulamak. Kurum } \\
\text { düzeyinde takım çalışmaları programı hazılamak. Birimler arası } \\
\text { takım çalışmaları yapabilmek ve desteklemek. Meslek içi } \\
\text { eğitimlerle takım ruhunu desteklemek. }\end{array}$ \\
\hline 2 & $\begin{array}{l}\text { Sosyal faaliyetler ve kültürel tanıtım faaliyetleri kadar teknik tanıtımlara } \\
\text { ağırlık vermek, gerekli kaynakları ayırmak, tanıtım faaliyetlerinde } \\
\text { vatandaştan faydalanmak ve katılımı sağlamak, yerinde tanıtım } \\
\text { yapmak, sinevizyon hazırlığını daha yaygın hale getirmek, farklı } \\
\text { bölgeler için farklı tanııı programları düzenlemek. Bu kapsamda } \\
\text { muhtarlar ve diğer sosyal kuruluşlardan ve özellikle bilgi meclisinden } \\
\text { faydalanmak, tanıtım programlarının etkinliğini düzenli olarak gözden } \\
\text { geçirmek ve sürekli iyileştirmek, tanıtım için bir birim veya ekip kurmak, } \\
\text { periyodik etkileşim toplantıları düzenlemek. }\end{array}$ \\
\hline
\end{tabular}




\begin{tabular}{|c|c|}
\hline 3 & $\begin{array}{l}\text { Sürekli iyileştirme çalışmalarının yaygınlaştırılması, ölçülmesi ve } \\
\text { kayıt altına alınması. Bu kapsamda vatandaş memnuniyeti, } \\
\text { çalışan memnuniyeti, iç müşteri memnuniyeti, süreç performans } \\
\text { ölçümleri v.b. ölçütler belirlenip hesaplanacak ve hedefler } \\
\text { konularak değerlendirmeler yapılacak. Birimler her yıl en az iki } \\
\text { kere özdeğerlendirme yaparak iyileştirmeye açı alanları } \\
\text { belirleyip takım çalışmaları yolu ile iyileştirmeler yapılacaktır. } \\
\text { İyileştirme çalışmalarının etkinliği ölçülecek. }\end{array}$ \\
\hline 4 & $\begin{array}{l}\text { Hedeflere dayalı bir yönetim ve performans değerlendirme } \\
\text { sistemi oluşturulacak. }\end{array}$ \\
\hline 5 & $\begin{array}{l}\text { Süreçlerle yönetim anlayışına geçilmesi, bu kapsamda süreçlerin } \\
\text { belirlenmesi ve iş analizlerinin yapılması sağlanacaktır. Bu sayede } \\
\text { personel ihtiyacı ortaya çıkacaktır. }\end{array}$ \\
\hline 6 & $\begin{array}{l}\text { E-Belediyeye geçiş. Bu kapsamda belediyenin bilgi işleminin } \\
\text { otomasyonunun sağlanması ve yerel ağ (intranet) kurulması } \\
\text { sağlanacaktır. }\end{array}$ \\
\hline 7 & $\begin{array}{l}\text { Kapısız ve penceresiz açık sistem yönetim ve çalışma } \\
\text { koşullarına geçilecek. Bu sayede iş odaklı bir çalışma sistemi } \\
\text { oluşturulacaktır. }\end{array}$ \\
\hline 8 & $\begin{array}{l}\text { Mobil zabıta karakolu oluşturmak. Zabıta hizmetlerini etkin bir } \\
\text { şekilde yürütmek. }\end{array}$ \\
\hline 9 & $\begin{array}{l}\text { Çevre temizlik vergisi ve emlak vergisini vermemiş olan } \\
\text { mükelleflerin belirlenmesi için gerekli çalışmalar yapmak. }\end{array}$ \\
\hline 10 & Kurumsal bir kimliği olan arşiv sistemine geçmek. \\
\hline 11 & $\begin{array}{l}\text { Sürekli iyileştirme ve katılımı sağlayabilmek için bir öneri/şikayet } \\
\text { sistemi oluşturulacak. Önerilerin değerlendirilmesi yapılacak ve } \\
\text { planlama sistemi geliştirilecektir. }\end{array}$ \\
\hline 12 & $\begin{array}{l}\text { İlçeyi yeşil bir kent haline getirmek, bazı mahallerinde park } \\
\text { alanları oluşturmak. Bu konuda belediyeye gelecek hibeler arsa } \\
\text { şeklinde özendirilecek. }\end{array}$ \\
\hline 13 & Beldemizde deprem senaryoları düzenleyerek önlem paketi oluşturmak. \\
\hline
\end{tabular}




\begin{tabular}{|c|c|}
\hline 14 & $\begin{array}{l}\text { Başıboş hayvanların ıslah evlerinde barındııılması ve } \\
\text { büyükşehir nezdinde girişimlerde bulunulması, vatandaştan } \\
\text { yardım istenmesi. }\end{array}$ \\
\hline 15 & $\begin{array}{l}\text { Yoğun sinek bölgesi olduğundan ilçede bulunan gölün ve } \\
\text { derenin ıslah edilmesi ve larva oluşumunun önlenmesi için } \\
\text { araştırmalar yapılması (elektronik sistemler) ve ilaçlamaya } \\
\text { devam edilmesi. Halk sağlığına önem vermek, koruyucu } \\
\text { hekimlik hizmetlerini geliştirmek, halkı bilinçlendirmek. }\end{array}$ \\
\hline 16 & $\begin{array}{l}\text { Kaçak hafriyat ve molozun dökülmemesi için vatandaşın } \\
\text { uyarılması, çeşitli güvenlik önlemlerinin alınması, moloz } \\
\text { taşıyıcılarından menşei belgesi istenmesi, belediyenin kendisinin } \\
\text { moloz taşıma hizmeti vermesi. }\end{array}$ \\
\hline 17 & $\begin{array}{l}\text { Çağın gereklerine uygun belediyecilik hizmetlerini en etkin } \\
\text { şekilde üretmek ve çarpık kentleşmeyi önleyecek ve planlama } \\
\text { yapmak için hükümet nezdinde görüşmelerde bulunmak ve } \\
\text { projeler üretmek. }\end{array}$ \\
\hline 18 & $\begin{array}{l}\text { Kültürel ve sportif faaliyetlerde Tuzla sahili ve Kafkale Spor } \\
\text { Kompleksini etkin olarak kullanmak. }\end{array}$ \\
\hline 19 & $\begin{array}{l}\text { İlçede yatıım yapabilecek kurumlarla iletişim içinde olarak bu } \\
\text { kurumların yatırım programları ile belediye yatıım programının } \\
\text { uyumlu hale gelmesini sağlamak, bu kurumları yatırıma teşvik } \\
\text { etmek. }\end{array}$ \\
\hline 20 & İlçede hobi kültürünü artırmak. \\
\hline 21 & $\begin{array}{l}\text { Halkı belediyecilik hizmetleri konusunda bilinçlendirmek, yerel } \\
\text { yönetimler okulu açmak. }\end{array}$ \\
\hline
\end{tabular}

\section{Kurumsal Bilginin Stratejik Planlama Sürecinde Kullanılması}

Belediyenin stratejik planlama sürecinde kurumsal bilgiden istifade ettiği görülmüştür. Bu süreçte misyon bildirimi, vizyon bildirimi, belediyenin kuvvetli ve zayıf yönleri, karşılaştığı fırsatlar ve tehditler belirlenirken kurumsal bilgiden istifade edilmiştir. 
Belediyenin misyonu, belediyenin çalışma sahası; temel amacı ise etkilediği kitle ve bu kitleyi nasıl etkilediği sorularına cevap verilerek oluşturulmuştur. Belediye bu bildirimi hazırlarken kurumsal bilgi olarak, birimlere ait iş süreçlerinden, görev ve çalışma yönetmeliğinden ve faaliyet raporundan faydalanılmıştır. Belediyenin tüm birimlerin her bildirimdeki her bir ifadeyi desteklemesi, ya da o ifadeye dayanak teşkil etmesi mümkün değildir. Bu nedenle, tüm birimleri tek tek sıralamak yerine, bildirimlerde geçen ifadeleri destekleyen birimlere yer vermek daha uygun görülmüştür.

Belediyenin vizyon bildirimi, ağılıklı olarak İmar Müdürlüğü, Fen İşleri Müdürlüğü, Park ve Bahçeler Müdürlüğü, Basın, Yayın ve Halkla İlişkiler Müdürlüğü'nün görev ve çalışma yönetmeliğinden ve stratejik planlama kılavuzuna göre belediyenin temel değerleri arasında yer alan ifadelerden faydalanarak hazırlanmıştır.

Belediyenin kuvvetli yönleri belirlenirken, belediye dâhilindeki bütün birimlerden kendilerini yeterli gördükleri ya da sahip oldukları bazı özellikler dolayısıyla avantajı olduklarını düşündükleri hususları bildirmeleri istenmiş, ardından bu hususlar doğruluğu tespit edilerek genelleştirilmiş ve kurumsal kuvvetli yönler ortaya çıkarılmıştır.

Belediyenin zayıf yönleri için ise, tüm birimlerden, kendilerini yetersiz gördükleri ya da güçlendirilmesi gerektiğini düşündükleri hususları bildirmeleri istenmiş, ardından bu hususların doğruluğu tahlil edilerek, genelleştirilmiş ve kurumsal zayıf yönler ortaya çıkarılmıştır.

Büyükşehir Belediyesi sınırları içinde olmak, Belediye için bir fırsat sayılabilir Büyükşehir Belediyelerinin imkanlarının fazla olması ve eksikliklerin giderilmesi için yardımcı unsur olması, Büyükşehir Belediyesi dâhilindeki belediyeler için bir avantajdır. İlçe sınırları içindeki turistik tesisler, sahil yolu üzerindeki alanlar, mevcut spor tesisleri belediye için önemli gelir kaynakları oluşturmaktadır. Ayrıca, sahil kesimi de, İçmeler tesisi gibi, belediye için maddi kazanç sağlamaktadır. Bunun yanında ilçede bulunan spor kompleksi, Türkiye'nin en büyük spor kompleksi olma özelliğiyle ilçe için bir fırsattır. 
Öte yandan ilçe belediyesinin, Büyükşehir belediyesi sınırları içinde olması fırsat olmasının yanı sıra tehdit unsuru da oluşturmaktadır. Bunun nedeni, bütün ilçe belediyelerin dış işlerinde Büyükşehir belediyesine bağlı olması, dolayısıyla hareket alanlarının kısıtlanıyor olmasıdır.

Belediye kurumsal stratejilerini ve kalite hedeflerini, sahip olduğu fırsatlar ve karşı karşıya olduğu tehditlerle, kurumun kuvvetli ve zayıf yönlerinden ortaya çıkan sonuca göre belirlemiştir. Buna göre, kurumun kuvvetli yönleri ve sahip olduğu fırsatlar daha da pekiştirilmek ve güçlendirilmek amaçlı, zayıf yönleri ve tehdit unsurları da tedavi edilmek amaçlı olarak, kurumsal stratejilerin ve kalite hedeflerinin belirlenmesine dayanak teşkil etmiştir.

Kurumlar açısından 21. yüzyılın yok edici rekabeti ifade ediyor olması, ellerindeki bilgiyi sistemli bir biçimde yönetmelerini, stratejik öneme sahip bilgileri diğerlerinden ayırt etmeyi ve bilgi intiyacını doğru saptamayı gerekli kılmaktadır. Bununla beraber, rakiplerini çok yakından takip etmelerini, meydana gelebilecek değişimleri önceden tahmin etmelerini ve bu değişimlere öncülük etmelerini zorunlu kılmaktadır.

Ortamın bu derece zorlu oluşunun neticesinde, kurumların başarılı ilerleme stratejileri oluşturabilmeleri için, stratejik planlamanın öneminin daha da artığı şüphesizdir. Ancak stratejik planlamadan beklenen faydanın sağlanabilmesi için, kurumsal bilginin iş süreçlerine ve iş yapış şekillerine adapte edilmesi gerekmektedir. Çünkü bir kurumun başarısını belirleyen temel ölçüt, yapılan işin diğer kurumların yaptığından farkıdır. Yani önemli olan fark yaratmaktır. Kurumların fark yaratma stratejisini belirleyen kaynak ise kurumsal bilgidir. Dolayısıyla kurumların başarıya ulaşmaları için hem geçmişi yani kurumsal bilgiyi dikkate almaları, hem de geleceği şekillendirmek için stratejik planlama yapmaları gerekmektedir.

\section{Sonuç}

2004 yılında gündeme gelen, İ Özel İdareleri, Belediyeler ve Büyükşehir Belediyelerini de kapsayan kamu reformu tasarısı ile kamu yönetiminde şeffaflık, katılımcılık, etkinlik ve hizmetlerin hedef vatandaş kitlesine en yakın yerde üretilmesi ilkelerinin hayat 
geçirilmesi hedeflenmektedir. Bunun neticesinde kamu yönetiminin girdi odaklı hizmet anlayışı yerine, sonuç ve hedef odaklı hizmet anlayışını benimsemesi beklenmektedir.

Kamu kurumlarında bilginin iletilmesi, kurumun resmi yapısı içinde, belirlenmiş kurallar dahilinde gerçekleşmektedir. Bir kamu birimi olan belediyelerde de aynı anlayış hakimdir.

Belediyelerde çok kademeli bir yapının olması dolayısıyla, herhangi bir hizmetin tanımlanabilmesi için bilgi ve belgelerin yatay ve dikey yönde çok defa gidip gelmesi gerekmektedir. Bu durum bir yandan zaman kaybı yaratarak hizmet maliyetlerinin artmasına neden olmakta, diğer yandan örgüt yapısı içinde gerek birimler gerekse bireyler arasındaki iletişimi ortadan kaldırarak, yatay iletişim ağlarının kurulmasına engel olmaktadır. Böyle bir verimsizliğin ortadan kalkması, hem kurumsal bilgi kaynaklarından en üst düzeyde istifade edilmesini hem de stratejik planlama sürecinin sağlıklı bir şekilde devam etmesini sağlayacaktır.

\section{Kaynakça}

Aktan, C. C. (2003). Geleceği kazanmanın yolu: Stratejik yönetim. 11 Eylül 2003 tarihinde http://www.canaktan.org/canaktan _personal/canaktan-arastirmalari/toplam-kalite/aktan-stratejikyonetim.pdf adresinden erişildi.

Argüden, Y. (2004). Geleceği şekillendirmek yaşam kalitesi için stratejik düşünmek. İstanbul: Rota.

Arıkboğa , Ş. F. (2003). Entellektüel sermaye. İstanbul: Derin.

Barca, M. (2002). Yeni ekonomide bilgi yönetiminin stratejik önemi. I.Dalay (Yay. Haz.). Stratejik boyutuyla modern yönetim yaklaşımları içinde (ss.65-83). İstanbul: Beta.

Büyüközkan, G (2003). Entellektüel sermaye yönetimi. 2 Kasım 2003 tarihinde http://www.kalder.org adresinden erişildi.

Dalay, İ. (2001). Yönetim ve organizasyon, ilkeler, teoriler ve stratejiler. Sakarya: Sakarya Üniversitesi.

Drucker, P. (1994). Sonuç için yönetim. (B. Toksöz, Çev.). İstanbul: İnkılap. 
Elma, C. ve Demir K. (Ed.). (2000). Yönetimde çağdaş yaklaşımlar, uygulamalar ve sorunlar. Ankara: Anı Yayıncılık.

Eren, E. (1990). İşletmelerde stratejik planlama ve yönetim. İstanbul: İstanbul Üniversitesi İşletme Fakültesi.

Kamuda Stratejik Yönetim. (2003). Belediyeler. 16 Eylül 2003 tarihinde http://www.sp.gov.tr/ yerel.html adresinden erişildi.

Kırım, A. (1998). Yeni dünyada strateji ve yönetim. İstanbul: Sistem.

Odabaş, H. ve Rukancı, F. (2004). Belge Yönetiminin Bir Unsuru Olarak Yazışma Yönetimi. Türk Kütüphaneciliği, 18(4), 385-406.

Odabaş, H. (2003). Kurumsal Bilgi Yönetimi. Türk Kütüphaneciliği, 17 (4), 357-368.

Özdemirci, F. ve Aydın, C. (2007). Kurumsal Bilgi Kaynakları ve Bilgi Yönetimi. Türk Kütüphaneciliği, 21(2), 164-185.

Yazıcı, S. (2001). Öğrenen organizasyonlar. İstanbul: Alfa. 